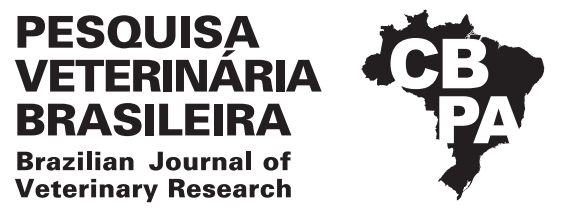

Pesq. Vet. Bras. 38(11):2080-2087, novembro 2018 DOI: $10.1590 / 1678-5150-P V B-5765$

Original Article

Animais de Produção/Livestock Diseases

ISSN 0100-736X (Print)

ISSN 1678-5150 (Online)

\title{
Causes of death in goats in Rio Grande do Sul state, Brazil: analysis of 322 cases $(2000-2016)^{1}$
}

\author{
Daniele M. Bassuino ${ }^{2,3}$, Guilherme Konradt², Matheus V. Bianchi², \\ Gustavo G.M. Snel ${ }^{4}$, Luciana Sonne ${ }^{2}$, Saulo P. Pavarini ${ }^{2}$ and David Driemeier ${ }^{2 *}$
}

\begin{abstract}
Bassuino D.M., Konradt G., Bianchi M.V., Snel G.G.M., Sonne L., Pavarini S.P. \& Driemeier D. 2018. Causes of death in goats in Rio Grande do Sul state, Brazil: analysis of 322 cases (2000-2016). Pesquisa Veterinária Brasileira 38(11):2080-2087. Setor de Patologia Veterinária, Departamento de Patologia Clínica Veterinária, Faculdade de Veterinária, Universidade Federal do Rio Grande do Sul, Av. Bento Gonçalves 9090, Porto Alegre, RS 91540-000, Brazil. E-mail: davetpat@ufrgs.br

The diagnosis of the cause of death in goats submitted to necropsy from January 2000 to December 2016 by Setor de Patologia Veterinária from the Universidade Federal do Rio Grande do Sul was reviewed. Epidemiological features, such as the breed, sex and age, in addition to the clinical and pathological features were evaluated. During this period, 322 goats were necropsied, in which a conclusive diagnosis was obtained in 290 (90\%) goats. Goats that were part of other experimental study were excluded from this study. From these 290 cases, 167 (57.6\%) corresponded to diseases of infectious origin and toxinfectious diseases, while $123(42.4 \%)$ were classified as non-infectious conditions. Infectious diseases included 55 cases of bacterial origin, 59 cases with parasitary involvement, 14 cases of viral origin, and 39 toxinfectious cases. Non-infectious conditions were grouped into metabolic diseases (44 cases), plants or chemical substances poisoning (36), mineral and nutritional deficiencies (20), and neoplasms and developmental disorders (5). In the remaining 18 cases, a conclusive diagnosis was obtained, however the conditions did not fit into those criteria and were classified as "others". The age range of the goats in this study was from 1 day-old to 10 years-old. Most of the goats were females (201), while 121 were males. Affected breeds included Boer, Saanen, Anglo-Nubian, Toggenburg and mixed breeds. Parasitic, infectious and toxin-infectious diseases were the main cause of deaths, especially haemonchosis, pleuropneumonia, eimeriosis and enterotoxemia. Among the non-infectious conditions, metabolic disorders, especially rumen acidosis, pregnancy toxemia and urolithiasis, were directly related to the management employed in the property. Plant poisoning diagnosis was also highlighted with locally present plants, such as Sida carpinifolia, as the most important.
\end{abstract}

INDEX TERMS: Causes of death, goats, Rio Grande do Sul, diagnosis, pathology, small ruminants, infectious diseases.

RESUMO.- [Causas de morte em caprinos diagnosticadas no estado do Rio Grande do Sul: análise de 322 casos (2000-2016).] Foram revisadas as causas de morte de

\footnotetext{
${ }^{1}$ Received on April 13, 2018.

Accepted for publication on May 7, 2018.

${ }^{2}$ Setor de Patologia Veterinária, Universidade Federal do Rio Grande do Sul (UFRGS), Av. Bento Gonçalves 9090, Porto Alegre, RS 91540-000, Brazil. *Corresponding author: davetpat@ufrgs.br

${ }^{3}$ Universidade de Cruz Alta (Unicruz), Rodovia Municipal Jacob Della Méa Km 5.6, Cruz Alta, RS 98005-972, Brazil.

${ }^{4}$ Fellowship CAPES/Brazil (Ciência sem Fronteiras Program, Italy-Brazil).
}

caprinos submetidos ao exame de necropsia no período compreendido entre janeiro de 2000 e dezembro de 2016 pelo Setor de Patologia Veterinária da Universidade Federal do Estado do Rio Grande do Sul, Brasil. Avaliaram-se os dados epidemiológicos relacionados à raça, sexo e idade, assim como as alterações macroscópicas e microscópicas observadas. Durante esse período, foram recebidos para necropsia 322 caprinos, nos quais em 290 casos (90\%) foi obtido o diagnóstico conclusivo. Caprinos destinados à experimentação animal foram excluídos deste estudo. Do total de 290 casos, 167 (57,6\%) corresponderam a enfermidades 
de origem infecciosa e toxi-infecciosa, enquanto $123(42,4 \%)$ em causas não infecciosas. Entre as doenças infecciosas foram contabilizados 55 casos de origem bacteriana, 59 casos com envolvimento parasitário, 14 casos de origem viral, e 39 casos toxi-infecciosos. As doenças de caráter não infeccioso foram agrupadas em doenças metabólicas (44 casos), intoxicações por plantas ou substâncias tóxicas (36), deficiências minerais e nutricionais (20), neoplasias e distúrbios no desenvolvimento (5). Dezoito casos com diagnóstico conclusivo, mas que não se enquadravam nestas classificações foram agrupadas como "outros". A faixa etária dos caprinos neste estudo variou de um dia a 10 anos. A maior parte dos animais eram fêmeas (201), enquanto 121 eram machos. As raças dos caprinos necropsiados neste período incluíram Boer, Saanen, Anglo-Nubiano, Toggenburg e sem raça definida (SRD). As enfermidades de origem parasitárias, infecciosas e toxi-infecciosas, especialmente hemoncose, eimeriose, pleuropneumonias e a enterotoxemia acarretaram o maior número de mortes. Das causas não infecciosas, distúrbios metabólicos, como acidose lática ruminal, toxemia da prenhez e urolitíase, estiveram diretamente relacionadas com o manejo empregado nas propriedades. Evidenciou-se também a importância do diagnóstico de intoxicações por plantas relevantes da região, como Sida carpinifolia.

TERMOS DE INDEXAÇÃO: Causas de morte, caprinos, Rio Grande do Sul, diagnóstico, patologia, pequenos ruminantes, doenças infecciosas.

\section{INTRODUCTION}

Goat/sheep farming has been a prominent activity in the Brazilian agribusiness with a herd estimated at 14 million animals distributed on 436,000 agricultural establishments (Brasil 2015). In 2015, the national caprine herd reached the number of $9,614,722$ with an increase of $8.6 \%$ compared to 2014 (IBGE 2015). The progressive growth of goat farming was accompanied by an increase in the productive capacity of this species, which has been achieved through several aspects, especially to the genetic improvement aiming an increase in milk and meat production (Resende et al. 2008). Goats are affected by several diseases, including some that are common to other livestock ruminants, while others are specific for this species and may present a zoonotic behavior (Kumar et al. 2003). Rosa et al. (2013) described the causes of death in caprine diagnosed in the central region of Rio Grande do Sul through a retrospective study in a 48-year period in which the infectious and parasitic causes were the most common causes of death, accounting for $40.35 \%$ of the conclusive diagnosis. On the other hand, Debien et al. (2013) diagnosed the causes of death of 152 necropsied goats in Quebec, and the most frequent diseases included enterotoxemia (17.1\%), pneumonia (13.8\%), Johne's disease (10.5\%), listeriosis (6.6\%), pregnancy toxemia (5.3\%), caprine arthritis encephalitis (4.6\%), and caseous lymphadenitis (3.9\%). Kusiluka et al. (1998) highlighted the importance of ectoparasites and endoparasites in goat farming, and concluded that the helminths, diarrheas and respiratory diseases were the main causes of death and were directly influenced by the handling in the properties of Tanzania. The knowledge regarding the local and regional realities of goat farming is essential to elaborate preventive strategies, aiming the improvement in the sanitary, nutritional and productive aspects for this species. However, retrospective studies addressing the causes of death in goats in Brazil are scarce, making it hard to estimate the economic losses related to these deaths in this activity (Rosa et al. 2013). The aim of this study is to determine the frequency and the clinical-pathological features of the main causes of death diagnosed in goats in Rio Grande do Sul state, Brazil, from January 2000 to December 2016.

\section{MATERIALS AND METHODS}

A retrospective study aiming the causes of death in goats was conducted through the analysis of the necropsy reports database from the Setor de Patologia Veterinária of Universidade Federal do Rio Grande do Sul, SPV-UFRGS from January 2000 to December 2016. All goats were from Rio Grande do Sul state, mainly from the metropolitan area of Porto Alegre. Data regarding the epidemiological features, such as age, sex and breed were grouped and registered, as well as the clinical signs, pathological findings and the conclusive diagnosis. These were finally grouped into two main categories: infectious diseases and non-infectious diseases. Infectious diseases were further subdivided in bacterial, viral, parasitic, and toxic infectious diseases, while noninfectious diseases were subdivided as metabolic, plant and chemical substances poisonings, mineral and nutritional deficiency, developmental disorders and neoplasms. Cases that did fit in the above-mentioned etiologies were categorized as "others".

\section{RESULTS}

In the analyzed period, 322 goats were submitted to necropsy and evaluated in this study, from which 290 (90\%) cases had a conclusive diagnosis, while $32(10 \%)$ were inconclusive. From all the 290 cases, 167 (57.6\%) corresponded to infectious and toxinfectious diseases, $123(42.4 \%)$ to noninfectious diseases, and $18(6.2 \%)$ corresponded to "others". From the infectious diseases, 59 of the cases were caused by parasites, 55 by bacteria, 39 toxinfectious, and 14 by virus. The frequency of occurrence of infectious and toxinfectious conditions is shown in Table 1.

The infectious parasitic diseases, mainly represented by haemonchosis and eimeriosis, were the main causes of death in goats in this study with $14.5 \%$ and $3.5 \%$ of the cases, respectively. Haemonchus sp. parasitism caused the death of 42 goats from four months-old to eight years-old, usually with an endemic occurrence on the herds. Eight of these goats were from properties in which Haemonchus sp. outbreaks occurred with a mortality rate varying from 8 to $12 \%$. The other cases occurred individually on the evaluated herds. Clinically, there were weight loss, apathy, anorexia, submandibular edema, opaque and unruly skin, anemia and diarrhea in a clinical evolution of two to seven days. The necropsy findings were characterized by generalized pallor of the mucosa, blood with an aqueous aspect, ascites, hydropericardium, pallor of viscera in the abdominal cavity, epicardial serous atrophy, mesentery and mesocolon edema, and large amounts of adhered or free filiform and cylindrical reddish parasites (morphologically compatible with Haemonchus sp.) in the abomasum. The abomasum content had an aqueous aspect with a dark reddish color. Haemonchosis diagnosis was obtained through the epidemiological features, clinical signs, and pathological findings, and it was facilitated by the observation of large amounts of parasites compatible with Haemonchus sp. within the abomasum. Eimeriosis affected 10 goats from 30 days-old 
Table 1. Infectious and toxinfectious diseases diagnosed in goats in Rio Grande do Sul state, Brazil

\begin{tabular}{|c|c|}
\hline Infectious diseases & Number of cases \\
\hline \multicolumn{2}{|l|}{ Bacterial } \\
\hline Bacterial pleuropneumonia & 26 \\
\hline Septicemias & 11 \\
\hline Abscedative necrotic hepatitis & 4 \\
\hline Listeriosis & 3 \\
\hline Bacterial enteritis & 2 \\
\hline Suppurative meningitis (Escherichia coli) & 3 \\
\hline Caseous lymphadenitis & 1 \\
\hline Suppurative meningoencephalomyelitis & 1 \\
\hline Acute bacterial mastitis & 1 \\
\hline Paratuberculosis & 1 \\
\hline Salmonellosis & 1 \\
\hline Rhodococcosis & 1 \\
\hline \multicolumn{2}{|l|}{ Parasitic } \\
\hline Haemonchosis & 42 \\
\hline Eimeriosis & 10 \\
\hline Toxoplasmosis & 4 \\
\hline Verminous pneumonia (Muellerius capillaris) & 2 \\
\hline Cenurosis & 1 \\
\hline \multicolumn{2}{|l|}{ Toxinfectious } \\
\hline Clostridium perfringens type D Enterotoxemia & 35 \\
\hline Tetanus & 3 \\
\hline Neurotoxicosis (Aspergillus clavatus) & 1 \\
\hline \multicolumn{2}{|l|}{ Viral } \\
\hline Caprine arthritis-encephalitis & 7 \\
\hline Viral pneumonia & 4 \\
\hline Contagious ectima & 3 \\
\hline TOTAL & 167 \\
\hline
\end{tabular}

to four months-old, with death rates that varied from $8 \%$ to $15 \%$ in the attended herds. Two necropsied goats were from two outbreaks on distinct properties that had death rates from $11 \%$ to $13 \%$. Environmental and handling factors, such as high stocking densities and a mixture of animals from different categories and ages were related to these cases. The clinical signs were characterized by weight loss, reduced growth, and chronic diarrhea, in a clinical course of 30 to 40 days. At necropsy, there were mild white nodular elevated lesions ranging from 0.5 to $1.5 \mathrm{~cm}$ in diameter in the small intestine's mucosa, predominantly involving the jejunum and ileum segments, in addition to diffuse pale mucosae and submandibular subcutaneous edema. Histologically, villous hyperplasia and intestinal crypts associated with numerous protozoal structures in different developmental phases, including macrogametocytes and microgametocytes, morphologically compatible with Eimeria sp., as well as associated inflammatory infiltrate of lymphocytes, plasma cells and macrophages on the lamina propria.

Bacterial diseases accounted for $19 \%$ of the cases (55/290), of which pleuropneumonia was the most common diagnosis, with $9 \%$ of all the causes of death in goats of the present study. Goats had an age range of 10 months-old to 4 years-old, with a death rate of $8 \%$ within the herds, and a lethality of $90 \%$.
The outbreaks occurred in association to predisposing factors of stress, mainly due to prolonged transport and environmental changes. Clinically, there were apathy, fever, cough, mucopurulent nasal discharge, and dyspnea, with a clinical course of two to five days. At necropsy, there were extensive multifocal to coalescent areas of cranioventral consolidation of the lungs associated to fibrin deposits over the visceral pleura, as well as pleural adhesions, in addition to marked pulmonary edema. Microscopical lesions consisted of abundant inflammatory infiltrate involving the alveoli, bronchi and bronchioles of viable and degenerate neutrophils, as well as mild number of lymphocytes and macrophages frequently associated to fibrin deposits on the visceral pleura, in addition to marked and diffuse alveolar edema. Mannheimia haemolytica was identified in 22 cases through bacteriological and molecular analysis; Escherichia coli and Streptococcus sp. were isolated in one case each through microbiological culture.

Viral diseases occurred in 14 cases (4.8\%), of which caprine arthritis encephalitis virus (CAEV) was diagnosed in seven cases $(2.4 \%)$. Affected goats were females with an age range of 10 to 12 days-old, predominantly raised in semi-intensive system. The condition had mainly an endemic occurrence in properties that presented a history of neurological disorders in young and adult animals with pneumonia and lameness as well. Common pathological findings included multifocal lymphoplasmacytic meningoencephalitis with perivascular cuffs and areas of moderate microgliosis. Moreover, four goats also had pneumonia and interstitial mastitis, which were compatible with the infection by CAEV.

In the toxinfectious category, Clostridium perfringens type D enterotoxemia was the most frequent diagnosis, accounting for $35(12 \%)$ cases of the conclusive diagnosis. The age ranged from 17 days-old to 4 years-old, with an occurrence in outbreaks reaching mortality rates of $5 \%$ to $20 \%$, and a lethality of $100 \%$. Predominantly, the goats were originated from unvaccinated herds, or previously vaccinated in less than four months. Clinical signs varied from sudden death to apathy, anorexia, fever, intense abdominal pain, and in some cases diarrhea with a clinical course of 12 hours to 3 days. At necropsy, there were intense congestion of the serous layer of the intestines, in addition to distension of the small and large intestine, which were filled by large amounts of reddish liquid occasionally containing filaments of fibrin content at the final segment of the ileum, cecum and colon. The kidneys had a gelatinous aspect and soft consistency (pulpy kidney). Histologically, there was a mild to moderate necrosis of the intestinal villi associated to fibrin deposition over the mucosa, in addition to basophilic bacillary bacteria and necrotic debris. The submucosa had also a diffuse inflammatory infiltrate composed of lymphocytes, macrophages and plasma cells. The kidneys had a diffuse and severe autolysis. The diagnosis was confirmed through clinical history, pathological aspects, and associated to the detection of the agent by microbiological culture, and by serum neutralization test in mice.

The noninfectious diseases were grouped into metabolic diseases, which represented 44 cases (15.2\%); plants poisoning or chemical toxic substances with 36 cases $(12.4 \%)$; mineral and nutritional deficiencies with 20 cases (6.9\%); neoplasms and development disorders with 5 of the cases (1.7\%). In this category, the following conditions were the most frequent: ruminal lactic acidosis with 17 cases (5.8\%), pregnancy 
toxemia in 13 cases (4.5\%), and urolithiasis in 10 cases (3.4\%). The frequency of the noninfectious conditions in goats is presented in Table 2 .

Ruminal lactic acidosis affected goats with an age range of eight months-old to four years-old, and it was mainly associated to employment of highly fermentable diets (corn, rice, and wheat) administrated without a previous adaptation period of the animals. Most of the goats with ruminal lactic acidosis were from different properties which employed semi-intensive raising systems; however, most of the cases occurred individually. Yet, two goats were from properties in which outbreaks took place with mortality rates of up to $20 \%$. Clinical signs consisted of depression, anorexia, prostration, dehydration, abdominal distention, occasionally bloat and death, with a clinical course of 12 hours to 2 days. Necropsy findings were characterized by moderate to severe abdominal distention, with abundant yellowish liquid content intermixed by feed content (high concentration of grains) in rumen and reticulum, aside from multifocal reddish and ulcerated areas in the rumen mucosa. Histological lesions consisted of hydrophobic degeneration of the rumen mucosa with foci of inflammatory infiltrate of neutrophils and multifocal ulcerative areas of the mucosa.

Table 2. Non infectious diseases diagnosed in goats in Rio Grande do Sul state, Brazil

\begin{tabular}{lc}
\hline \multicolumn{1}{c}{ Non infectious diseases } & Number of cases \\
\hline Metabolical diseases & \\
Ruminal lactic acidosis & 17 \\
Pregnancy toxemia & 13 \\
Urolithiasis & 10 \\
Fibrous osteodystrophy & 3 \\
Primary bloat & 1 \\
Poisonings & \\
Poisoning by Sida carpinifolia & 11 \\
Acute toxic hepatopathy of unknown cause & 10 \\
Poisoning by defatted rice bran & 4 \\
Poisoning by Trema micrantha & 3 \\
Poisoning by Baccharis megapotamica & 2 \\
Poisoning by Prunus sphaerocarpa & 2 \\
Poisoning by coumarin derivatives & 2 \\
Poisoning by Amorimia exotropica & 1 \\
Poisoning by Dodonaea viscosa & 1 \\
Nutritional and mineral deficiencies & \\
Vitamin E and selenium deficiency & 10 \\
Malnutrition & 5 \\
Iodine deficiency (goiter) & 1 \\
Copper deficiency & 4 \\
Developmental disorders and neoplasms & 1 \\
Palatoschisis & \\
Vulvar agenesis & 1 \\
Pheochromocytoma & \\
Hypospadias & \\
Others & 1 \\
TOTAL & \\
& \\
\hline
\end{tabular}

Pregnancy toxemia was directly associated with the late stage of gestation of triplets and quadruplets, affecting goats with an age range of two to eight years-old. Predisposing factors included traumatic lesions, climate and environmental changes. Clinically, there were anorexia, locomotion problems, dehydration, blindness, staggered walk, decreased eyelid reflexes, recumbency, and death, with a clinical course of two to five days-old. At necropsy, the liver was slightly enlarged, yellowish, friable and, at the surface cut there was enhanced lobular pattern. Histologically, there was intense and diffuse microvacuolar hepatocellular degeneration (hepatic steatosis).

Urolithiasis affected 10 unneutered male goats (3.4\%), with an age range of two to three months-old. Only one case was associated to an outbreak, with a concomitant occurrence in seven other goats out of 60 in a herd. The remaining cases occurred individually in the properties. In three cases, there was rupture of the urinary bladder with subsequent uroperitoneum. Common necropsy findings included marked hyperemia of the urinary bladder mucosa, with abundant sandy sediments, and partially or completely obstruction of the urethra involving the sigmoid flexure, ischiatic curvature, or the urethral process. In addition to that, occasionally there were hydronephrosis and/or hydroureter.

Plants poisoning and chemical toxic substances poisoning accounted for $12.4 \%$ of total of cases, and included poisoning by Sida carpinifolia (11), by Trema micrantha (3), by Baccharis megapotamica (2), by cyanogenic plants, by Amorimia exotropica (1), by Dodonaea viscosa (1), as well as other 10 cases of acute hepatic necrosis suggestive of a toxic cause from distinct properties where the cause was not determined. There were another four cases of poisoning by defatted rice bran and two goats poisoned by coumarin derivatives. In these cases, the diagnosis was established through the gross and microscopical findings associated mainly to the epidemiological factors, which were acquired through visits to the properties and visualization of the suspected toxic plant, as well as through epidemiological surveys conducted with the producer and/or veterinarian responsible for the properties.

In the mineral and nutritional deficiencies category, the lack of vitamin E and selenium was diagnosed in 3.4\% of all diagnosed cases. Significant differences of age and sex of the affected goats were not observed. The goats necropsied were from two properties where outbreaks that affected several animals occurred, with mortality rates ranging from 8 to $10 \%$, and lethality rates near $100 \%$. The clinical signs included depression, muscle tremors, instability of thoracic and pelvic limbs with evolution to recumbency in a clinical course of one to five days. Grossly, extensive pale areas were observed in the cardiac and skeletal muscles, which histologically corresponded to coagulative necrosis of muscle fibers, characterized by fragmented and sometimes flocculate cytoplasm, with hypereosinophilic sarcoplasm and loss of striations, as well as pyknotic nuclei associated with an inflammatory infiltrate of macrophages and multifocal areas of mineralization.

\section{DISCUSSION}

Among the parasitic diseases, haemonchosis and eimeriosis were the main causes of death in this study, with $14.5 \%(42 / 290)$ and 3.5\% (10/290), respectively. The epidemiological and clinical findings of both conditions were similar to the observed by other authors (Miller et al. 2012, Rosa et al. 2013), with a clinical condition of anemia and hypoproteinemia associated 
with diarrhea (Uzal et al. 2016). Haemonchosis also was the main cause of death of goats in the retrospective study performed by Rosa et al. (2013) in the central region of Rio Grande do Sul state, as well as it was the main cause of death in sheep in this region (Rissi et al. 2010); in a study of the causes of death in goats in India related to the feeding system, haemonchosis represented the third most frequent condition. Haemonchus contortus is considered the most pathogenic nematode of goats due to its voracious hematophagous behavior (Smith \& Sherman 2009), and triggers a clinical condition of severe anemia and consequent characteristics clinical signs (Costa et al. 2009). Eimeriosis affects mainly young goats (Uzal et al. 2016), similar to the observed in this study, in which the age ranged from 1 to 4 months-old. This condition leads to economic losses due to the high morbidity and mortality, reduced growth and high costs with treatments (Kaya 2004, Temizel et al. 2011). The main species of Eimeria that cause clinical disease in caprine are: E. arloingi, E. christenseni and E. ninakohlyakimovae. These cause a morbidity that varies from $38 \%$ to $100 \%$ (Smith \& Sherman 2009), which is distinct from the observed in this study, in which goats were affected individually in the herds, and this may be directly influenced by the environmental and handling conditions of the species. The necropsy findings consisted of elevated white nodular lesions in the mucosa of the small intestine and large intestine, besides the histopathological lesions, which were similar to the described in the literature (Silva et al. 2014, Uzal et al. 2016).

Clostridium perfringens type D enterotoxemia represented the second infectious disease with higher impact in the mortality of goats in this study, accounting for $12 \%$ (35/290) of the cases of infectious and toxinfectious diseases. This is below than the observed in previous studies (Ershaduzzaman et al. 2007, Debien et al. 2013), and above from the found by Pawaiya et al. (2017). These differences may occur since casuistic is directly related with the different practices of handling employed in the properties. Predisposing factors include sudden modification of the gastrointestinal microbiota, which may occur with diets rich in carbohydrates, proteins and highly fermentable pastures, and are associated with the clinical disease, since it allows rapidly growth of $C$. perfringens and the production of its toxins (Kriek et al. 1994, Smith \& Sherman 2009). These factors are epidemiologically related with the number of cases in each property and were compatible with the ones found in the present study. Enterotoxemia affects goats of variable ages and the pathogenesis is influenced by production of alpha and epsilon toxin by the bacteria (Uzal \& Songer 2008, Nasir et al. 2013), however in the present study the diagnosis of the condition was based on the clinical, epidemiological and pathological aspects of the condition, sometimes associated to the detection of the agent by microbiological culture or through serum neutralization in mice (Colodel et al. 2003). Unvaccinated animals tolerate low levels of toxin without developing clinical signs (Uzal et al. 2002). Polyvalent vaccines provide smaller titers in goats when compared to the sheep (Uzal et al. 1998), as well as individuals may respond differently to the vaccine, depending on the vaccination intervals and on the adjuvants present in the vaccine. The higher mortality rate observed in this study was attributed to the absence of vaccination, as well as possible flaws in the process of immunization, aside from the short period between the vaccines and the challenge. Differential diagnosis for enterotoxemia included the conditions that cause sudden death in goats, such as other agents that cause diarrhea in adults (coccidiosis and salmonellosis) and also in young animals (cryptosporidiosis and colibacillosis) (Smith \& Sherman 2009). A retrospective study of the causes of death in goats in India that specifically involved the gastrointestinal tract demonstrated that enteritis, paratuberculosis, haemonchosis, inanition, gastrointestinal parasites, bloat, and enterotoxemia were also the main causes of death diagnosed over a 25 years period of the study (Pawaiya et al. 2017).

Bacterial pleuropneumonias represented $9 \%$ of the cases (26/290). Mannheimia haemolytica was identified in 22 cases through bacteriologic and molecular analysis. In one case, Escherichia coli was identified, and in another Streptococcus sp. was identified through microbiological analysis. The gross findings of pleuropneumonia by $M$. haemolytica in goats are similar to the observed in other ruminants, and include cranioventral areas of consolidation occasionally followed by fibrinous pleuritis (Caswell \& Williams 2016). Acute pulmonary infections caused by this agent are characterized by a necrotic and fibrinosuppurative inflammation that occurs in response to the release of $M$. haemolytica toxins, as well as the release of cytokines by neutrophils and other inflammatory cells (Yener et al. 2009). Microscopically, this condition is characterized by hemorrhage, alveolar necrosis, fibrin exudation, interlobular septal edema, as well as degenerate neutrophils with an 'oat' shape, which are characteristic of $M$. haemolytica lesions and essential for the pathological diagnosis (Smith \& Sherman 2009, Woolums \& Wilkins 2014, Caswell \& Williams 2016). Predisposing factors such as climate and stressful situations related to the handling are correlated with the emergence of cases of acute pneumonia (Caswell \& Williams 2016). Moreover, the mixture of animals of different origins increases the exposure to pathogenic agents. The cases of pleuropneumonia by $M$. haemolytica in goats of this study probably occurred due to the agglomeration of animals from different origins, which were also submitted to the prolonged transport as a stress factor. In addition to this condition, other possible common and concomitant diseases as cachexia and subclinical haemonchosis may increase the susceptibility of these animals to the bacteria.

CAEV infection was diagnosed in $2.4 \%$ of the cases of infectious origin (7/290). All goats necropsied in this study were young females. However, the infection by CAEV typically involves both males and females, of many breeds and age ranges (Rowe \& East 1997), in a way that is difficult to establish a possible predisposing factor associated to the sex or age of the goats affected due to several factors that may be associated to handling in a property. The clinical and anatomopathological presentation of the CAEV infection manifests in four basic clinical manners: nervous, articular, respiratory and mammary (Peretz et al. 1993). The articular form is the most prevalent in adult goats, while the nervous is considered the less important, and both are observed mainly in 1 to 4 months-old goats, or sporadically in older animals associated with polyarthritis (East et al. 1993, Callado et al. 2001). The goats of the present study had a lymphoplasmacytic meningoencephalitis as the most frequent form observed in the 
young females necropsied, which was occasionally associated to pneumonia and interstitial mastitis. The classic neurological lesion caused by CAEV is a demyelinating encephalomyelitis, though the myelinated fibers in the inflammatory focus stay intact in the initial phase of the disease (Cantile \& Youssef 2016). This may explain the absence of demyelinating lesions in the cases of the present study, since the analyzed goats were mostly in the beginning of the clinical evolution. The farming handling methods are important factors that contribute to the viral dissemination. In this study, the goats were predominantly raised in a semi-intensive system, which provides the agglomeration of the animals and favors the viral infection and the contamination of the environment (Castro \& Melo 2001). CAEV infections diagnosis is primarily based on the clinical findings and confirmed through the laboratorial tests for direct detection of the virus, its genetic material or by serological surveys (Pinheiro et al. 2009). The CAEV diagnosis in this study was based through the clinical and pathological findings associated to a previous history of endemic occurrence of the condition in the properties. Knowles (1997) reported that CAEV seroprevalence in a herd may reach $90 \%$; however, most of the animals have no clinical signs and represent a potential source of infection.

The non-infectious diseases accounted for $42.41 \%$ $(123 / 290)$ of the diagnosed cases. Ruminal acidosis was diagnosed in $5.8 \%(17 / 290)$ of the cases, and its occurrence was in according to previous descriptions of grain overload, with an abrupt change in the diet to high fermentation aliments that promote the growth of Gram-positive bacteria and the production of lactic acid (Gelberg 2013), which are common predisposing factors also observed in the goats of this study. The diagnosis in these cases was obtained through the observation of an aqueous ruminal content intermixed by large amounts of grains in the rumen, as well as detachment of ruminal mucosa associated with submucosal hyperemia., in addition to characteristic histological lesions, which included hydropic degeneration of the ruminal epithelium, with the formation of vesicles and areas of erosion and ulceration of the rumen mucosa (Afonso \& Mendonça 2007, Gelberg 2013).

Ketosis in goats usually occurs at the end of gestation (pregnancy toxemia) and also may occur during the lactation peak due to the negative energy balance of these periods (Smith \& Sherman 2009). In the present study, this condition was diagnosed in $4.5 \%(13 / 290)$ of the cases in which it was possible to observe a direct association of the condition in goats with gestations of triplets and quadruplets, aside to the predisposing stressful factors, such as periods of food restriction, feeding change at the end of gestation, transport, changes in the environment or climatic disturbances (Schild 2007), which were compatible with those reported in the historic by the producers in the cases of the present study.

Urolithiasis was diagnosed in $3.4 \%$ (10/290) of the cases. Uroliths may occur both in males and females, but obstruction is rarely observed in females due to the anatomical characteristics. All cases of urolithiasis involved 2 to 3 months-old males. This higher frequency observed in males is justified by a smaller urethral diameter with higher number of cases of obstructions verified in the sigmoid flexure, ischial curvature and urethral process (Riet-Correa et al. 2008), as observed in the cases of this study. Ruminants fed with grains or its sub products are more prone to develop urolithiasis due to a reduced saliva production and the high content of phosphorus in these aliments, as well as an increased formation of mucoproteins in the urine that contribute to form the organic core of calculi (Radostits et al. 2000).

The diagnosis of plant poisoning and chemical toxic substances poisoning accounted for $12.4 \%$ (36/290) of the cases. Toxic plants of animal interest lead to significant losses in the production of livestock, with direct losses related to animal mortality (Riet-Correa \& Medeiros 2001). Sida carpinifolia, Trema micrantha and Baccharis megapotamica poisonings were the most prevalent in this study, which differs from other retrospective studies conducted in different regions of Brazil (Silva et al. 2006, Mello et al. 2010). These data reinforce the importance of these regional studies in determining the frequency of some diseases.

The vitamin $\mathrm{E}$ and selenium deficiency occurs in animals maintained in pastures where the soil is poor in vitamin $\mathrm{E}$ and selenium, or that are fed with deficient feed in these elements (Radostits et al. 2000). In this study, this deficiency represented $3.4 \%$ of the cases (10/290), which is below to the observed by Rosa et al. (2013) that described high mortality rates in the outbreaks, especially in young goats. In the Rio Grande do Sul state, mortality outbreaks in goats related to this deficiency have already been described by Loretti et al. (2001) in goats of many ages, similar to the one observed in the present study in which no breed, sex or age range predisposition was observed.

\section{CONCLUSIONS}

The parasitic infections and toxinfectious diseases, especially haemonchosis, eimeriosis, pleuropneumonias and enterotoxemia were the most frequently diagnosed diseases in the analyzed period.

Among the non-infectious conditions, metabolic disturbances were highlighted, especially ruminal lactic acidosis, pregnancy toxemia, and urolithiasis, which are diseases directly related to the handling in a property, while the relevant plant poisoning was represented by Sida carpinifolia poisoning.

\section{REFERÊNCIAS}

Afonso J.A.B. \& Mendonça C.L. 2007. Acidose láctica ruminal, p.313-319. In: Riet-Correa F., Schild A.L., Lemos R.A.A. \& Borges J.R.J. (Eds). Doenças de Ruminantes e Equídeos. Vol.2. 3a ed. Palloti, Santa Maria. 691p.

Brasil. 2015. Ministério da Agricultura, Pecuária e Abastecimento. Caprinos e Ovinos. Available at <http://www.agricultura.gov.br/animal/especies/ caprinos-e-ovinos> Accessed on Jan. 1, 2017.

Callado A.K.C., Castro R.S. \& Teixeira M.F.S. 2001. Lentivírus de pequenos ruminantes (AEV e Maedi-Visna): revisão e perspectivas. Pesq. Vet. Bras. 21(3):87-97. <http://dx.doi.org/10.1590/S0100-736X2001000300001>

Cantile C. \& Youssef S. 2016. Nervous System, p.251-406. In: Jubb K.V.F., Kennedy P.C. \& Palmer's N. Pathology of Domestic Animals. Vol.1. 6th ed. Academic Press, New York. 796p.

Castro R.S. \& Melo L.E.H. 2001. CAEV e Maedi-Visna: importância na saúde e produtividade de caprinos e ovinos e a necessidade de seu controle no Nordeste brasileiro. Ciênc. Vet. Trop. 4(2/3):315-320. 
Caswell J.L. \& Williams K.J. 2016. Respiratory system, p.465-592. In: Jubb K.V.F., Kennedy P.C. \& Palmer's N (Eds), Pathology of Domestic Animals. Vol.2. 6th ed. Academic Press, New York. 592p.

Colodel E.M., Driemeier D., Schmitz M., Germer M., Nascimento R.A.P., Assis R.A., Lobato F.C.F. \& Uzal F.A. 2003. Enterotoxemia em caprinos no Rio Grande do Sul. Pesq. Vet. Bras. 23(4):173-178.<http://dx.doi.org/10.1590/ S0100-736X2003000400006>

Costa V.M.M., Simões S.V.D. \& Riet-Correa F. 2009. Doenças parasitárias em ruminantes no semi-árido brasileiro. Pesq. Vet. Bras. 29(7):563-568 <http://dx.doi.org/10.1590/S0100-736X2009000700011>

Debien E., Hélie P., Buczinski S., Lebœuf A., Bélanger D. \& Drolet R. 2013. Proportional mortality: a study of 152 goats submitted for necropsy from 13 goat herds in Quebec, with a special focus on caseous lymphadenitis Can. Vet. J. 54(6):581-587. <PMid:24155449>

East N.E., Rowe W.J., Dahlberg J.E., Theilen G.H. \& Pederson N.C. 1993. Models of transmission of caprine arthritis encefalites virus infection. Small Rumin. Res.10(3):251-262. <http://dx.doi.org/10.1016/0921-4488(93)90130-A>

Ershaduzzaman M., Rahman M.M., Roy B.K. \& Chowdhury S.A. 2007. Studies on the diseases and mortality pattern of goats under farm conditions and some factors affecting mortality and survival rates in black bengal kids. Bangl. J. Vet. Med. 5:71-76.

Gelberg H.B. 2013. Sistema Alimentar, Peritônio, Omento, Mesentério e Cavidade Peritonial, p.323-406. In: Zachary J. \& McGavin M.D (Eds.), Bases da Patologia Veterinária. 5a ed. Elsevier. Rio de Janeiro. 1344p.

IBGE 2015. Produção da Pecuária Municipal. Instituto Brasileiro de Geografia e Estatística. Available at <http://biblioteca.ibge.gov.br/visualizacao/ periodicos/84/ppm_2015_v43_br.pdf> Accessed on Jan.1, 2017.

Kaya G. 2004. Prevalence of Eimeria species in lambs in Antakya province. Turk J. Vet. Anim. Sci. 28:687-692.

Knowles Junior J.R.D.P. 1997. Laboratory diagnostic tests for retrovirus infections of small ruminants. Vet. Clin. N. Am., Food Anim. Pract. 13(1):1-11 <http://dx.doi.org/10.1016/S0749-0720(15)30361-3><PMid:9071743>

Kriek N.P.J., Odendaal M.W. \& Hunter P. 1994. Clostridium perfringens type D enterotoxaemia, p.1315-1322. In: Coetzer J.A.W., Thomson G.R., Tustin R.C. (Eds), Infectious Diseases of Livestock with Special Reference to Southern Africa. Oxford: Oxford University Press, Cape Town. 874p.

Kumar S., Vihan V.S. \& Deoghare P.R. 2003. Economic implication of diseases in goats in India with reference to implementation of a health plan calendar Small Rumin. Res. 47(2):159-164. <http://dx.doi.org/10.1016/S09214488(02)00237-7>

Kusiluka L.J.M., Kambarage D.M., Harrison L.J.S., Daborn C.J. \& Matthewman R.W. 1998. Causes of morbidity and mortality in goats in Morogoro district, Tanzania: the influence of management. Small Rumin. Res. 29(2):167-172. <http://dx.doi.org/10.1016/S0921-4488(97)00110-7>

Loretti A.P., Driemeier D., Traverso S.D. \& Seitz A.L. 2001. Miopatia nutricional em caprinos no Rio Grande do Sul. Anais 10 Encontro Nacional de Patologia Veterinária, Pirassununga, SP, p.36. (Resumo)

Mello G.W.S., Oliveira D.M., Carvalho C.J.S., Pires L.V., Costa F.A.L., Riet-Correa F. \& Silva S.M.M. 2010. Plantas tóxicas para ruminantes e equídeos no Norte Piauiense. Pesq. Vet. Bras. 30(1):1-9. <http://dx.doi.org/10.1590/ S0100-736X2010000100001>

Miller J.E., Kaplan R.M. \& Pugh D.G. 2012. Internal parasites, 125p. In: Pugh D.G. \& Baird A.N. (Eds), Sheep and Goat Medicin. 2nd ed. Elsevier Saunders. <http://dx.doi.org/10.1016/B978-1-4377-2353-3.10006-X>.

Nasir A.A., Younus M., Rehman M.U., Lateef M., Khaliq S.A., Ahmad I. \& Abbas M. 2013. Hematological and some biochemical alterations in sheep experimentally infected with $C$. perfringens type D infection. J. Anim. Plant Sci. 23:1553-1558.
Pawaiya R.V.S., Singh D.D., Gangwar N.K., Gururaj K., Kumar V., Paul S., Sharma N., Mishra A.K., Kumar A., Sharma D.K. \& Singh S.V. 2017. Retrospective study on mortality of goats due to alimentary system diseases in an organized farm. Small Rum. Res. 149:141-146. <http://dx.doi.org/10.1016/j. smallrumres.2017.02.007>

Peretz G., Asso J. \& Devillechaise P. 1993. Le C.A.E.V.: revue des connaissances actuelles et consequences pratiques. Rev. Méd. Vét. 144:93-98.

Pinheiro R.R., Ximenes L.J.F., Pinheiro A.A. \& Teixeira M.F.S. 2009. Lentivírus de Pequenos Ruminantes: Diagnóstico, Prevenção e Vacinas. Embrapa Caprinos e Ovinos. Available at <https://www.alice.cnptia.embrapa.br/ bitstream/doc/572791/1/PLRizaldo.pdf> Accessed on Mar. 1, 2018.

Radostits O.M., Gay C.C., Blood D.C. \& Hinchcliff K.W. 2000. Clínica Veterinária: um tratado de doenças dos bovinos, ovinos, suínos, caprinos e equinos. 9a ed. W.B. Saunders, London, p.441-447.

Resende K.T., Silva H.G.O., Lima L.D. \& Teixeira I.A.M.A. 2008. Avaliação das exigências nutricionais de pequenos ruminantes pelos sistemas de alimentação recentemente publicados. Revta Bras. Zootec. 37(spe):161177. <http://dx.doi.org/10.1590/S1516-35982008001300019>

Riet-Correa F. \& Medeiros R.M.T. 2001. Intoxicações por plantas em ruminantes no Brasil e no Uruguai: importância econômica, controle e riscos para a saúde pública. Pesq. Vet. Bras. 21(1):38-42.<http://dx.doi.org/10.1590/ S0100-736X2001000100008>

Riet-Correa F., Simões S.V.D. \& Vasconcelos J.S. 2008. Urolitíase em caprinos e ovinos. Pesq. Vet. Bras. 28(6):319-322. <http://dx.doi.org/10.1590/ S0100-736X2008000600010>

Rissi D.R., Pierezan F., Oliveira Filho J.C., Fighera R.A., Irigoyen L.F., Kommers G.D. \& Barros C.S.L. 2010. Doença de ovinos da região Central do Rio Grande do Sul: 361 casos. Pesq. Vet. Bras. 30(1):21-28. <http://dx.doi. org/10.1590/S0100-736X2010000100004>

Rosa F.B., Caprioli R.A., Silva T.M., Galiza G.J.N., Barros C.S.L., Irigoyen L.F., Fighera R.A. \& Kommers G.D. 2013. Doenças de caprinos diagnosticadas na região Central no Rio Grande do Sul: 114 casos. Pesq. Vet. Bras. 33(2):199204. <http://dx.doi.org/10.1590/S0100-736X2013000200011>

Rowe J.D. \& East N.E. 1997. Risk factors for transmission and methods for control of Caprine Arthritis-Encephalitis virus infection. Vet. Clin. N. Am., Food Anim. Pract. 13:34-53.

Schild A.L. 2007. Cetose, p.281-286. In: Riet-Correa F., Schild A.L., Lemos R.A.A. \& Borges J.R.J. (Eds), Doenças de Ruminantes e Equídeos. Vol.2. 3aㅗ ed. Palloti. Santa Maria. 691p.

Silva D.M., Riet-Correa F., Medeiros R.M.T. \& Oliveira O.F. 2006. Plantas tóxicas para ruminantes e equídeos no Seridó Ocidental e Oriental no Rio Grande do Norte. Pesq. Vet. Bras. 26(4):223-236. <http://dx.doi.org/10.1590/ S0100-736X2006000400007>

Silva L.M.R., Vila-Viçosa M.J.M., Nunes T., Taubert A., Hermosilla C. \& Cortes H.C.E. 2014. Eimeria infections in goats in Southern Portugal. Braz. J. Vet. Parasitol. 23(2):280-286. <http://dx.doi.org/10.1590/S1984-29612014051> $<$ PMid:25054515>

Smith M.C. \& Sherman D.M. 2009. Goat Medicine. 2nd ed. Wiley-Blackwell, Iowa. 871p. <http://dx.doi.org/10.1002/9780813818825>.

Temizel E.M., Demir G., Selcuk O., Catık S., Senlik B. \& Senturk S. 2011. Effect of treatment with cylindamycine in an outbreak of coccidiosis in goat kids in Turkey. J. Biol. Environ. Sci. 5(13):37-40.

Uzal F.A. \& Songer J.G. 2008. Diagnosis of C. perfringens intestinal infections in sheep and goats. J. Vet. Diagn. Invest. 20(3):253-265. <http://dx.doi. org/10.1177/104063870802000301 ><PMid:18460610>

Uzal F.A., Plattner B.L. \& Hostetter J.M. 2016. Alimentary system, p.1-259. In: Jubb K.V.F., Kennedy P.C., \& Palmer's N. (Eds), Pathology of Domestic Animals. Vol.2. 6th ed. Academic Press, New York. 592p. 
Uzal F.A., Bodero D.A., Kelly W.R. \& Nielsen K. 1998. Variability of serum antibody responses of goat kids to a commercial Clostridium perfingens epsilon toxoid vaccine. Vet. Rec. 143(17):472-474. <http://dx.doi. org/10.1136/vr.143.17.472><PMid:9829304>

Uzal F.A., Kelly W.R., Morris W.E. \& Assis R.A. 2002. Effects of intravenous injection of Clostridium perfringens type D epsilon toxin in calves. J. Comp. Pathol. 126(1):71-75. <http://dx.doi.org/10.1053/jcpa.2001.0514> <PMid:11814324>
Woolums A.R. \& Wilkins P.A. 2014. Diseases of respiratory system, p.461637. In: Smith B. (Ed.), Large Animal Internal Medicine. 5th ed. Mosby Elsevier. 1712p.

Yener Z., Ilhan F., Ilhan Z. \& Saglam Y.S. 2009. Immunohistochemical detection of Mannheimia (Pasteurella) haemolytica antigens in goats with natural pneumonia. Vet. Res. Commun. 33(4):305-313.<http://dx.doi.org/10.1007/ s11259-008-9178-z><PMid:18972219> 